International Journal of Business Management and Economic Review

Vol. 4, No. 06; 2021

ISSN: 2581-4664

\title{
DO JOB STRESS, EMOTIONAL INTELLIGENCE, AND WORKLOAD CONTRIBUTE TO THE VARIATION OF EMPLOYEE PERFORMANCE?
}

\author{
I Made Manu Parisuda and I Gusti Ayu Manuati Dewi \\ Faculty of Economics and Business, Udayana University, Bali, Indonesia
}

http://doi.org/10.35409/IJBMER.2021.3335

\begin{abstract}
The purpose of this study was to explain the role of job stress in mediating the effect of emotional intelligence and workload on employee performance. The population in this study were all employees of Desak Putu Putera Cottages Group. The total sample in this study was 102 employees which was determinate by saturated sampling technique. Testing the hypothesis of this study using the technical analysis of Structural Equation Modeling (SEM) based on Partial Least Square (PLS). The results show that emotional intelligence has a positive and significant effect on employee performance, workload has a negative and significant effect on employee performance, emotional intelligence has a negative and significant effect on job stress, workload has a positive and significant effect on job stress, job stress has a negative and negative effect on performance. employees, and job stress partially mediate the effect of emotional intelligence and workload on employee performance. The implication of the research shows that the job stress variable has the highest influence on employee performance, followed by the influence of emotional intelligence on employee performance. Thus, the management of Desak Putu Putera Cottages Group should pay more attention to the work stress experienced by its employees and the workload received by its employees.
\end{abstract}

Keyword: Employee Performance, Emotional Intelligence, Workload, Job Stress

\section{INTRODUCTION}

Employee performance problems are things that are often faced by companies. This can hinder the achievement of company goals, so the company must improve the performance of each employee. Decrease in employee performance can occur due to several things, one of which is the low emotional intelligence of employees. Emotional intelligence is a factor as important as technical and analytical skills to produce optimal employee performance. Robbins and Judge (2015: 70) define emotional intelligence as a person's ability to assess emotions in oneself and others, understand the meaning of emotions, and regulate one's emotions on a regular basis. To achieve success in the world of work is not only cognitive ability, but also emotional intelligence. Emotional intelligence is the other side of intelligence that is important for humans, because it has an important role in determining the level of success in life and is one of the factors that can affect employee performance (Prajuna, et al. 2017).

According to Dhani \& Sharma (2017), emotional intelligence has a positive and significant effect on employee performance. In their research, companies should include emotional intelligence in the selection and training process, to improve employee performance which will 


\section{International Journal of Business Management and Economic Review}

Vol. 4, No. 06; 2021

ISSN: 2581-4664

lead to company growth. Mohamad \& Jais (2016) stated that in order to maintain employee performance, companies must develop and improve the emotional intelligence of employees. Companies must recognize

the important role of emotional intelligence in developing human resources that lead to a high- performance workforce. Research conducted by Fitriastuti (2013) states that emotional intelligence has a significant positive effect on employee performance. The results of this study are in line with Shahhosseini et al. (2012) which suggests that emotional intelligence and employee performance in their research have a positive and significant correlation. Naghdi \& Badri (2013) suggested that emotional intelligence can contribute to one's achievement. Gong et al. (2019) suggests that employees' emotional intelligence has a significant positive role in predicting their job performance. In other words, in a company or organization, the higher the level of emotional intelligence that employees have, the better their performance will be.

However, there is one study proposed by Hidayati (2013) that the analysis shows that there is no influence of emotional intelligence on employee performance. Looking at the explanation of Aghdasi, et al (2011) which states that the influence of emotional intelligence with other variables is not significant, one of which is caused by the organizational structure studied is a public organization, where in public organizations decision making is usually top-down (from top to bottom). If it is associated with employee performance indicators, one of which is initiative and leadership, where good performance can be seen from the ability to make decisions, it can be the cause of the lack of emotional intelligence on employee performance.

In addition to emotional intelligence, workload can also reduce employee performance. According to Sunyoto (2012), workload is a process or activity that is too much and can cause tension in a person. This can lead to a decrease in employee performance caused by the level of expertise demanded is too high, the work speed may be too high, the work volume may be too much and so on. Arie (2015) states that workload is a worker's perception of a set of activities that must be completed within a certain time limit, both in the form of physical and psychological workloads. Yamin et al. (2020) stated in his research that workload had a negative effect on the performance of inpatient nurses at Sawerigading Hospital, Palopo City. This means that if the workload carried out by nurses is very large, it will reduce their performance, and vice versa. In addition, Johari et al. (2018) suggests that workload has an effect but is not significant on teacher performance in Malaysia.

Research conducted by Shabbir \& Naqvi (2017) suggests that workload has a negative and significant effect on employee performance. Akob (2016) states that workload has a negative effect on employee performance. The same thing was stated by Wakoli (2016) in his research on workload on teacher performance in Bungoma, Kenya. Different research results were put forward by Shah et al (2011), the results of this study suggest that workload has a positive effect on employee performance. The high workload carried out by supervisors is very important, because it is related to performance and bonuses received by employees. Workload is not always the reason for the decline in employee performance. The workload if it can be processed and utilized will actually improve the performance of the employee.

Job stress is one of the variables that affect employee performance. Robbins (2016: 429) suggests that job stress is an unpleasant psychological process that occurs in response to 


\section{International Journal of Business Management and Economic Review}

Vol. 4, No. 06; 2021

ISSN: 2581-4664

environmental pressure. According to Mangkunegara (2013) job stress is a depressed feeling experienced by an employee in dealing with work which can result in unstable emotions, feelings of restlessness, aloofness, and difficulty sleeping. Job stress affects the condition of employees, so that excessive stress can threaten someone in carrying out their activities and interfere with their work. Someone who experiences job stress will show a decreased physical condition, caused by something that cannot be overcome in his work. According to Ahmad et al. (2018) job stress has a negative and significant effect on employee performance. This means that when a person experiences job stress, his performance will decrease. Job stress makes employees unable to concentrate properly on their work. Similar results were also obtained by Vijayan (2018) in his research, which states that management can take the necessary steps to be able to control employee job stress levels so that employee performance increases.

However, research conducted by Olusegun, et al. (2014) stated that there is a positive and significant effect of job stress on employee performance. Positive job stress is needed in employees in the company, therefore to improve employee performance, one of them is through the role of superiors. The level of stress on employees if maintained and managed properly, it will be able to increase the effectiveness of these employees. If stress is not managed properly, then employee productivity will be disrupted. Therefore, stress management needs to be considered by the company to overcome the stress experienced by employees.

The correlation between employee performance, emotional intelligence, workload, and job stress has actually been stated in several previous research results. Karambut \& Noormijati (2012) in their research stated that emotional intelligence has a significant negative effect on job stress, because the higher emotional intelligence, the lower the job stress, and vice versa. Choi et al. (2019) stated in his research that emotional intelligence has a significant effect on job stress for hotel employees in South Korea.

Research conducted by Pratama \& Satrya (2018), stated that an increase in workload accompanied by a lack of time to do work and a lack of opportunity to make decisions at work resulted in an increase in job stress. Kokoroko \& Sanda (2019) stated in their research that workload has a positive effect on their job stress, such as the workload of nurses increasing workrelated stress levels as well.

Rafiee et al. (2013) stated in the results of the study that the job stress variable acts as a partial mediator on the influence of emotional intelligence on employee performance. Research conducted by Sanjaya (2012) shows results that indicate that emotional intelligence weakens the effect of job stress on performance. Abdillah (2013) states that emotional intelligence has an indirect effect on employee performance through job stress. This shows that employees who are able to identify, utilize, understand, and manage their emotions well will indirectly tend to have good work results through low job stress.

Shabbir \& Naqvi (2017) state that job stress mediates the effect of workload on employee performance. Research conducted by Martini \& Sitiari (2018) states that job stress partially mediates the effect of workload on employee performance. This means that employees must be able to control the level of job stress they experience caused by several factors, which can affect their performance. 
International Journal of Business Management and Economic Review

Vol. 4, No. 06; 2021

ISSN: 2581-4664

\section{LITERATURE REVIEW AND HYPOTHESES DEVELOPMENT}

Research conducted by Fitriastuti (2013) emotional intelligence has a significant positive effect on employee performance, which means that when the emotional intelligence of employees is high, employees will be able to show their best performance. The results of this study are in line with Shahhosseini et al (2012) where the independent variable (emotional intelligence) and the dependent variable (employee performance) in their research there is a positive and significant correlation between the two variables. Naghdi \& Badri (2013) suggested that emotional intelligence can contribute to a person's achievement, the higher the emotional intelligence possessed by a person, the person can handle his work well and provide his maximum ability. Gong et al. (2019) suggests that employees' emotional intelligence has a significant positive role in predicting their job performance. In other words, in a company or organization, the higher the level of emotional intelligence that employees have, the better their performance will be.

H1: Emotional intelligence has a positive and significant effect on employee performance

Workload has a negative and significant effect on employee performance. This is described in a study conducted by Paramitadewi (2017). The negative effect of workload on employee performance means that the lower the employee's workload, the higher the employee's performance. Similar results were also obtained by Kusuma \& Soesatyo (2014). Research conducted by Shabbir \& Naqvi (2017) found that workload has a negative and significant effect on employee performance. Akob (2016) states that workload has a negative effect on employee performance. The same thing was stated by Wakoli (2016) in his research on workload on teacher performance in Bungoma, Kenya. Research conducted by Chandra \& Adriansyah (2017) and Iskandar \& Sembada (2012) shows that there is a negative and significant effect of workload on employee performance. Gozali (2016) in his research stated that the workload had a negative and significant effect on the performance of the Central Bureau of Statistics employees in Deli Serdang and Serdang Begawai Regencies.

H2: Workload has a negative and significant effect on employee performance

Darvish's research (2011), proves that there is a negative and significant relationship between emotional intelligence and job stress, which means that high emotional intelligence will lower the job stress experienced by workers, and vice versa if the employee's emotional intelligence is low, the worker will find it difficult to control stress. what he experienced. Similar results were obtained by Goswani (2013), namely there was a negative and significant influence between emotional intelligence and job stress. Mangkunegara (2013) found that emotional intelligence had a negative effect on job stress, Megha (2014) found that there was a significant relationship between emotional intelligence and job stress.

H3: Emotional intelligence has a negative and significant effect on job stress

Research conducted by Pratama \& Satrya (2018) at the Bali Provincial Transportation Service shows that workload has a positive and significant effect on job stress. This is because an increase in workload accompanied by a lack of time to do work and a lack of opportunity to be able to make decisions at work results in an increase in job stress. Lestari \& Utama (2017) state that workload

has a positive and significant effect on job stress. Yo \& Surya (2015) in their research found that workload and job stress had a positive and significant relationship. Research conducted 


\section{International Journal of Business Management and Economic Review}

Vol. 4, No. 06; 2021

ISSN: 2581-4664

by Kusuma \& Soesatyo (2014) found that workload has a positive effect on job stress. Shabbir \& Naqvi (2017) state that workload has a positive and significant effect on job stress. Research by Rizky \& Afrianty (2018) at the Social Service of East Java Province states that workload affects job stress in a significant positive manner. Wijaya (2018) states that workload has a positive effect on job stress. Aujada, Saryadi, \& Nugraha (2015) state that workload has a significant positive effect on job stress.

$\mathrm{H} 4$ : Workload has a positive and significant effect on job stress

Research on job stress and employee performance by Ahmad et al. (2018) showed a negative and significant effect of job stress on employee performance. Kotteeswari \& Sharief (2014) stated that job stress affects employee performance. Job stress makes employees unable to concentrate properly on their work. Similar results were also obtained in Vijayan's research (2018), which states that management can take the necessary steps to control employee job stress levels so that employee performance increases. Shahid (2012) states that job stress has a negative effect on the performance of bank employees in Faisalabad, Pakistan. Ahmed \& Ramzan (2013) in their research on the banking sector in Pakistan stated that job stress significantly reduces employee performance. Saranani (2015) and Kristanti (2017) state that job stress has a negative and significant effect on employee performance. Kusuma \& Soesatyo (2014) research also states that job stress has a significant negative effect on employee performance.

H5: Job stress has a negative and significant effect on employee performance

Abdillah (2013) states that emotional intelligence has an indirect effect on employee performance through job stress. This shows that employees who are able to identify, utilize, understand, and manage their emotions well will indirectly tend to have good work results through low job stress. Rafiee (2013) stated in the results of the study that the job stress variable acts as a partial mediator on the influence of emotional intelligence on employee performance. Research conducted by Sanjaya (2012) shows results indicating that job stress mediates the effect of emotional intelligence on employee performance.

H6: Job stress mediates the effect of emotional intelligence on employee performance

Stress at work can be a serious problem for organizations as well as employees. One of the real effects of job stress is to create an imbalance between individual abilities, needs, and expectations and what organizations ask individuals to do (Alkubaisi, 2015). Shabbir \& Naqvi (2017) state that job stress mediates the effect of workload on employee performance. Research conducted by Martini \& Sitiari (2018) states that job stress partially mediates the effect of workload on employee performance.

H7: Job stress mediates the effect of workload on employee performance.

\section{METHODS}

The location for this research is Desak Putu Putera Cottages Group (three different branches) located in Ubud, Bali, Indonesia. The population in this study were the employees of Desak Putu Putera Cottages Group, which amounted to 102 employees Determination of the sample used in this study using the type of saturated sample method. This is motivated by the fact that the total population is slightly larger than 100 respondents, so it was decided to take $100 \%$ of the sample from the population, which is a total of 102 respondents. 
International Journal of Business Management and Economic Review

Vol. 4, No. 06; 2021

ISSN: 2581-4664

Hypothesis testing is done by comparing the $t$-table value with $t$-statistics and $p$ value with a significant level of 5 percent. If the t-statistic is higher than the t-table value, it means that the hypothesis is supported or accepted. The calculation results can directly be seen the path coefficient and total effect. This research uses the PLS.

\section{RESULTS AND DISCUSSION} PLS Test Results

1) Evaluation of the Measurement Model (Outer Model)

Evaluation of the measurement model is an evaluation of the relationship between variables and their dimensions. In technical data analysis using Smart PLS, there are three criteria to evaluate the measurement model, namely convergent validity by looking at the outer loading on each indicator, discriminant validity and composite reliability. Figure 1 shows the results of Smart PLS.

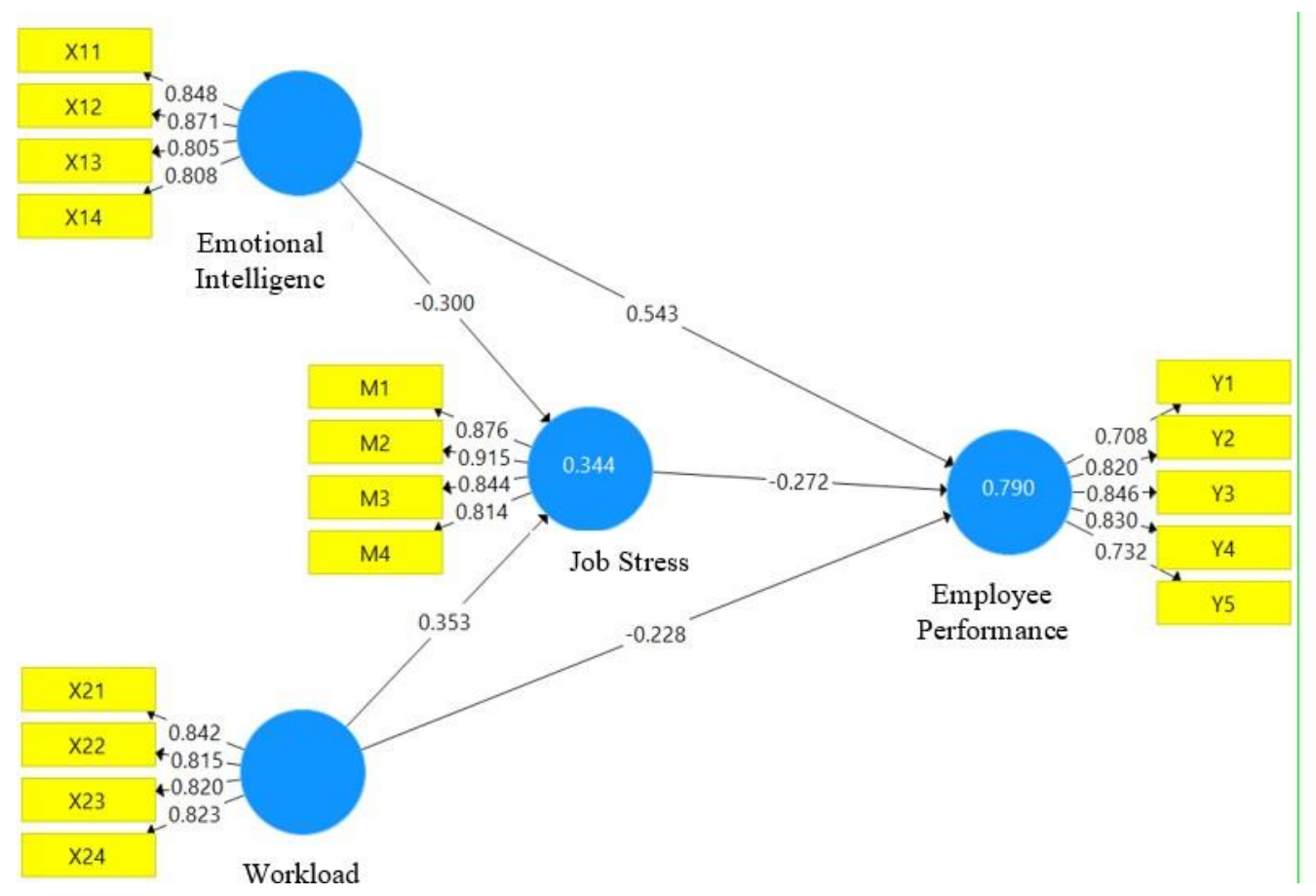

Figure 1. Outer Value Model PLS Path Diagram

The outer loading describes how much the indicators relate to the variables. The outer loading value on the path diagram is presented in Table 5.8, showing that the outer loading on each indicator provides a value above the recommended value of 0.5 . Thus, the indicators used in this study are valid or meet convergent validity.

Table 1. Outer Loading

\begin{tabular}{|llc|}
\hline \multicolumn{1}{|c}{ Variable } & \multicolumn{1}{c|}{ Dimension } & Outer Loading \\
\hline Emotional & Emotional self-assessment & 0.843 \\
Intelligence & Evaluation of other people's emotions & 0.832
\end{tabular}




\section{International Journal of Business Management and Economic Review}

Vol. 4, No. 06; 2021

ISSN: 2581-4664

\begin{tabular}{|llc|}
\hline \hline \multirow{5}{*}{ Workload } & Use of emotions & 0.763 \\
& Emotion management & 0.812 \\
& Psychological demands & 0.833 \\
& Role ambiguity & 0.822 \\
& Concentration & 0.822 \\
& Work mental disorders & 0.821 \\
Job Stress & Work frustration & 0.878 \\
& Stress at work & 0.939 \\
& Feeling tense at work & 0.858 \\
Employee & Feeling worried & 0.840 \\
performance & Quality of work & 0.761 \\
& Quantity of work & 0.851 \\
& Responsibility for work & 0.870 \\
& Attitude of coworkers & 0.863 \\
& Meets formal performance requirements & 0.782 \\
\hline
\end{tabular}

Another method of convergent validity is to compare the average variance extracted (AVE) value of each construct with the correlation between other constructs in the model, it can be concluded that the construct has a good discriminant validity value or vice versa. Accordingly, it is recommended that the measurement value should be greater than 0.50 .

Table 2. AVE Convergent Validity

\begin{tabular}{|lc|}
\hline & Average Variance Extracted (AVE) \\
\hline Emotional Intelligence (X1) & 0.661 \\
Workload (X2) & 0.680 \\
Job Stress (M) & 0.774 \\
Employee Performance (Y) & 0.683 \\
\hline
\end{tabular}

Discriminant validity testing can be done in two ways, namely comparing with the AVE root with variable correlation and cross loading. The results of the discriminant validity test by comparing the AVE roots with the correlation variables are presented in Table 1 and Table 2, showing that the value of the square root of the AVE is greater than the correlation of each variable.

Table 3. Correlation Results Between Variables

\begin{tabular}{|lcccc|}
\hline & $\begin{array}{c}\text { Emotional } \\
\text { Intelligence } \\
\text { (X1) }\end{array}$ & Workload (X2) & Job Stress (M) & $\begin{array}{c}\text { Employee } \\
\text { Performanc } \\
\mathbf{e} \\
(\mathbf{Y})\end{array}$ \\
\hline Emotional Intelligence (X1) & 1.000 & -0.595 & -0.548 & 0.600 \\
Workload (X2) & -0.595 & 1,000 & 0.589 & -0.605 \\
Job Stress (M) & -0.548 & 0.589 & 1,000 & -0.633 \\
Employee Performance (Y) & 0.600 & -0.605 & -0.633 & 1.000 \\
\hline
\end{tabular}

Primary Data, 2021

Table 4. AVE Value and Square Root AVE

\begin{tabular}{|ccc|}
\hline Variable & AVE & Square Root AVE \\
\hline Emotional Intelligence $(\mathrm{X} 1)$ & 0.661 & 0.813
\end{tabular}


International Journal of Business Management and Economic Review

Vol. 4, No. 06; 2021

ISSN: 2581-4664

\begin{tabular}{|lll|}
\hline \hline Workload (X2) & 0.680 & 0.825 \\
Job Stress (M) & 0.774 & 0.878 \\
Employee Performance (Y) & 0.683 & 0.881 \\
\hline
\end{tabular}

Primary Data, 2021

The results of the cross loading are presented in Table 4 it can be seen that each indicator has the largest outer loading value when connected to other indicators. This shows that each indicator has correctly explained each variable. This proves that based on discriminant validity all indicators are valid.

Table 5. Discriminant Cross Loading Validity

\begin{tabular}{|ccccc|}
\hline & $\begin{array}{c}\text { Emotional Intelligence } \\
(\mathbf{X} 1)\end{array}$ & Workload (X2) & Employee Performance (Y) & Job Stress (M) \\
\hline $\mathrm{X}_{1.1}$ & 0.843 & -0.606 & 0.565 & -0.548 \\
$\mathrm{X}_{1.2}$ & 0.832 & -0.384 & 0.491 & -0.379 \\
$\mathrm{X}_{1.3}$ & 0.763 & -0.407 & 0.461 & -0.394 \\
$\mathrm{X}_{1.4}$ & 0.812 & -0.509 & 0.416 & -0.434 \\
$\mathrm{X}_{2.1}$ & -0.521 & 0.833 & -0.484 & 0.464 \\
$\mathrm{X}_{2.2}$ & -0.505 & 0.822 & -0.512 & 0.527 \\
$\mathrm{X}_{2.3}$ & -0.452 & 0.822 & -0.542 & 0.466 \\
$\mathrm{X}_{2.4}$ & -0.486 & 0.821 & -0.453 & 0.483 \\
$\mathrm{M}_{1}$ & -0.461 & 0.579 & -0.544 & 0.878 \\
$\mathrm{M}_{2}$ & -0.509 & 0.604 & -0.612 & 0.939 \\
$\mathrm{M}_{3}$ & -0.422 & 0.479 & -0.492 & 0.858 \\
$\mathrm{M}_{4}$ & -0.531 & 0.394 & -0.571 & 0.840 \\
$\mathrm{Y}_{1}$ & 0.441 & -0.378 & 0.761 & -0.433 \\
$\mathrm{Y}_{2}$ & 0.462 & -0.511 & 0.851 & -0.525 \\
$\mathrm{Y}_{3}$ & 0.556 & -0.516 & 0.870 & -0.542 \\
$\mathrm{Y}_{4}$ & 0.548 & -0.592 & 0.863 & -0.567 \\
$\mathrm{Y}_{5}$ & 0.462 & -0.477 & 0.782 & -0.535 \\
\hline
\end{tabular}

Primary Data, 2021

The last step to ensure that there are no measurement-related problems in the evaluation of the measurement model is to use composite reliability indicators. The indicator group of a variable is said to be reliable if it has composite reliability 0.7 . Table 5 shows that all variables have a composite reliability value above 0.7 so they are declared reliable.

Table 6. Composite Reliability

\begin{tabular}{|lc|}
\hline \multicolumn{1}{|c|}{ Variable } & Composite Reliability \\
\hline Emotional Intelligence (X1) & 0.895 \\
Workload (X2) & 0.886 \\
Job Stress (M) & 0.932 \\
\hline
\end{tabular}


International Journal of Business Management and Economic Review

Vol. 4, No. 06; 2021

ISSN: 2581-4664

Employee Performance (Y)

Primary Data, 2021

0.915

The next testing stage is that the feasibility of the measurement model can be known after bootstrapping. The results after bootstrapping can be seen in Figure 2. The feasibility of a model can also be seen from its t-statistical value, provided that the $t$-statistic must be greater than t-count 1.960 at a significance level of 0.05 .

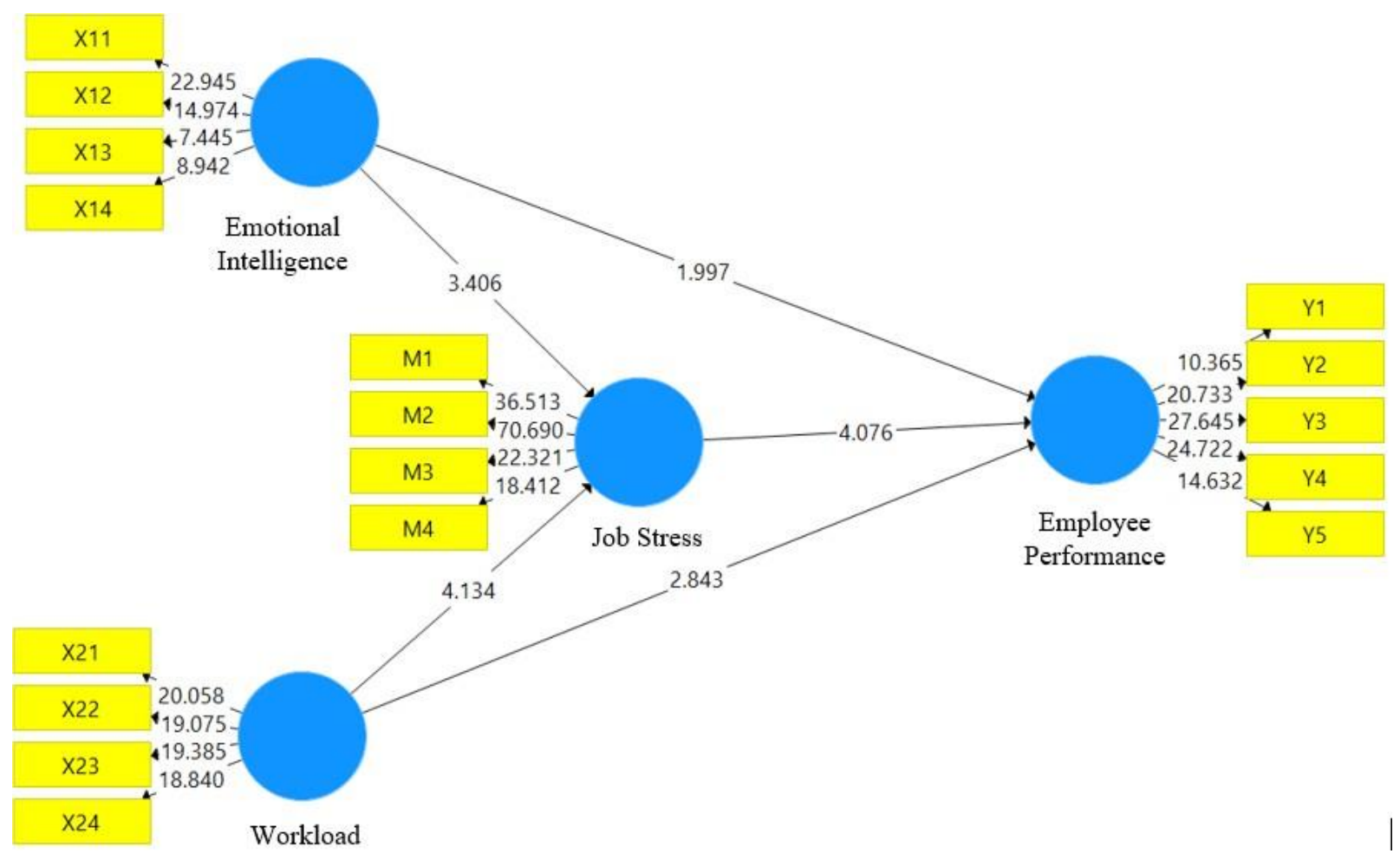

Figure 2. Bootstraping Results

2) Evaluation Results of the Measurement Model (Inner Model)

The measurement in the inner model uses R-Square dependent latent variable and QSquare predictive relevance which measures how well the observed values are generated by the model and also the estimated parameters. Assuming the data is distributed free, the structural model of the Partial Least Square (PLS) predictive approach is evaluated with R-Square for the dependent construct, on the contrary Q-Square test for predictive relevance.

(1) $\mathrm{R}$ - square

The R-square value is used to later calculate the Q-square value which is the goodness of fit model test. R-square also serves to determine how much (\%) the influence of exogenous variables on endogenous variables, the range of $\mathrm{R}$-square values is $0-1$. If the $\mathrm{R}$-square value is close to 0 , the weaker the influence of the exogenous variable on the endogenous variable, on the other hand, if it is close to 1 , the stronger the influence of the exogenous variable on the endogenous variable. 
International Journal of Business Management and Economic Review

Vol. 4, No. 06; 2021

ISSN: 2581-4664

\begin{tabular}{|cc|}
\hline \hline \multicolumn{1}{|c|}{ Table 7. R-square } & \\
\hline Variable & R Square \\
\hline Job Stress (M) & 0.407 \\
Employee Performance (Y) & 0.525 \\
\hline
\end{tabular}

Primary Data, 2021

Table 7 shows the R-square value for the job stress variable of 0.407 and the employee performance variable of 0.525 . These results indicate that the structural model in this study is categorized as good, because the larger the exogenous variables affect the endogenous variables.

(2) $\mathrm{Q}$ - square

The inner model test is done by looking at the Q-square value which is the goodness of fit test of the model. If the Q-square value is greater than 0 (zero) it shows that the model has predictive relevance, while the Q-square value is less than 0 (zero) indicating that the model lacks predictive relevance. Calculation of Q-square can be seen as follows:

$$
\begin{aligned}
& \mathrm{Q} 2=1-[(1-\mathrm{R} 12)(1-\mathrm{R} 2)] \\
& =1-[(1-0.407)(1-0.525)] \\
& =1-[(0.593)(0.475)] \\
& =1-(0.282) \\
& \mathrm{Q} 2=0.718
\end{aligned}
$$

The calculation results above show that the Q-square value of 0.718 is more than 0 , so it can be concluded that the model has predictive relevance or the model deserves to be said to have relevant predictive values.

Hypothesis Testing Results

1)Direct Effect

Testing the direct influence hypothesis using Partial Least Square (PLS) will show seven hypotheses. This test is carried out using the t-test (t-test) on each path of influence between variables. In PLS statistical testing of each hypothesized relationship is carried out using

\begin{tabular}{|c|c|c|c|c|}
\hline & $\begin{array}{c}\text { Path } \\
\text { Coefficient }\end{array}$ & t statistics & P Values & Description \\
\hline $\begin{array}{l}\text { Emotional Intelligence (X1) -> Employee } \\
\text { Performance (Y) }\end{array}$ & 0.268 & 1,997 & 0.046 & Significant \\
\hline Workload (X2) -> Employee Performance (Y) & -0.244 & 2,843 & 0.005 & Significant \\
\hline Emotional Intelligence (X1) -> Job Stress (M) & -0.305 & 3,406 & 0.001 & Significant \\
\hline Workload (X2) -> Job stress (M) & 0.407 & 4,134 & 0.000 & Significant \\
\hline Job Stress (M) -> Employee Performance (Y) & -0.343 & 4.076 & 0.000 & Significant \\
\hline
\end{tabular}
simulation. In this case, the bootstrap method is applied to the sample. Testing with bootstrap is also intended to minimize the problem of abnormal research data. The results of testing the direct effect with bootstrapping from the PLS analysis can be seen in Table 8.

Table 8. Direct Effect Test Results

Primary Data, 2021

The Effect of Emotional Intelligence on Employee Performance 


\section{International Journal of Business Management and Economic Review}

Vol. 4, No. 06; 2021

ISSN: 2581-4664

Hypothesis testing is done by using $\mathrm{t}$-statistics and looking at the $\mathrm{p}$-value. The value of $\mathrm{t}$ statistics value of $\mathrm{t}$-table (1.96) or p-value $<0.05$, then $\mathrm{H} 0$ is rejected and the research hypothesis is accepted. Table 8 shows that the emotional intelligence variable has a correlation coefficient value of 0.268 and a t statistics value of 1.997 on its effect on performance, then $\mathrm{H} 1$ is accepted. The results of the analysis show that emotional intelligence has a positive and significant effect on employee performance. Emotional intelligence is measured based on: self-assessment of emotions, evaluation of other people's emotions, use of emotions, emotional management can affect the performance of the employees of Desak Putu Putera Cottages Group. This means that the higher the emotional intelligence of the Desak Putu Putera Cottages Group employees, the better the performance. These results indicate that the values contained in emotional intelligence can be perceived well and have a real impact on the performance of the employees of Desak Putu Putera Cottages Group.

High emotional intelligence of employees is seen from good emotional self-assessment, being able to assess other people's emotions well, using emotions in problem solving and achieving goals well, and being able to manage one's own emotions well. With high emotional intelligence providing a link to high performance, which is reflected in the quality of work getting better, tasks can be completed on time, employees are able to fulfill the responsibilities given by the company, tasks that are expected by superiors to be completed well, and employees are able to fulfill formal requirements of the job.

The results of this study are in accordance with the results of previous research conducted by Fitriastuti (2013), which states that emotional intelligence has a significant positive effect on employee performance. The results of this study are also in line with previous research conducted by Shahhosseini et al (2012), Naghdi \& Badri (2013), and Gong et al. (2019).

\section{The Effect of Workload on Employee Performance}

The workload variable has a correlation coefficient value of -0.244 and a t statistic value of 2.843 on its effect on performance, then $\mathrm{H} 2$ is accepted. This shows that there is a negative influence between workload on performance. The higher the workload felt by the employee, the lower the performance shown by the employee. This shows that there is a positive influence between emotional intelligence on performance. The higher the emotional intelligence possessed by the employee, the higher the performance shown by the employee. This indicates that there is a positive influence between emotional intelligence on performance. The higher the emotional intelligence possessed by the employee, the higher the performance shown by the employee. The results of the analysis show that the workload has a negative and significant effect on employee performance. Workload which is measured based on: psychological demands, role ambiguity, concentration, and work mental disorders can affect the performance of the employees of Desak Putu Putera Cottages Group. This means that the higher the workload felt by the employees of Desak Putu Putera Cottages Group, the lower the performance. These results indicate that the values contained in the workload can be perceived well and have a real impact on the performance of the employees of Desak Putu Putera Cottages Group.

The high workload felt by employees can be seen from the psychological demands that interfere with their work, the perceived role ambiguity of the employee, lack of concentration at work, and experiencing mental disorders at work. With a high workload felt by employees giving 


\section{International Journal of Business Management and Economic Review}

Vol. 4, No. 06; 2021

ISSN: 2581-4664

a link to low performance, this is reflected in the quality of work getting worse as a result of employees feeling a high workload, work not being completed on time, lack of employee responsibility for their work, tasks expected by superiors are not fulfilled optimally, and the formal requirements of the job are not met.

The results of this study are in accordance with the results of previous research conducted by Paramitadewi (2017), which states that the negative effect of workload on employee performance means that the lower the employee's workload, the higher the employee's performance. These results also support previous research conducted by Kusuma \& Soesatyo (2014), Shabbir \& Naqvi (2017), Akob (2016), Wakoli (2016), Chandra \& Adriansyah (2017), Iskandar \& Sembada (2012)and Gozali (2016).

\section{Effect of Emotional Intelligence on Job Stress}

The emotional intelligence variable has a correlation coefficient value of -0.305 and a $t$ statistic value of 3.406 on its effect on job stress, then $\mathrm{H} 3$ is accepted. This shows that there is a negative influence between emotional intelligence on job stress. The higher the emotional intelligence possessed by the employee, the lower the job stress felt by the employee. Emotional intelligence is measured based on: self-assessment of emotions, evaluation of other people's emotions, use of emotions, emotional management is able to affect the job stress of the employees of Desak Putu Putera Cottages Group. This means that the higher the emotional intelligence of the Desak Putu Putera Cottages Group employees, the lower the perceived job stress. These results indicate that the values contained in emotional intelligence can be perceived well and have a real impact on job stress experienced by the employees of Desak Putu Putera Cottages Group.

High emotional intelligence of employees is seen from good emotional self-assessment, being able to assess other people's emotions well, using emotions in problem solving and achieving goals well, and being able to manage one's own emotions well. With high emotional intelligence, it is associated with low job stress, which is reflected by employee frustration at work, feelings of stress, feelings of tension, and anxiety when working decreases due to the management and use of good emotional intelligence.

The results of this study are in accordance with the results of previous research conducted by Darvish (2011), which proves that there is a negative and significant relationship between emotional intelligence and job stress. The results of this study also support several previous studies conducted by Goswani (2013), Mangkunegara (2013) and Megha (2014).

The Effect of Workload on Job stress

The workload variable has a correlation coefficient value of 0.407 and a t-statistic value of 4.134 on its effect on job stress, then $\mathrm{H} 4$ is accepted. This shows that there is a positive influence between workload and job stress. The higher the workload felt by employees, the higher the job stress they feel. The results of the analysis show that workload has a positive and significant effect on job stress. Workload which is measured based on: psychological demands, role ambiguity, concentration, and work mental disorders can affect the job stress of the employees of Desak Putu Putera Cottages Group. This means that the higher the workload of the Desak Putu Putera Cottages Group employees, the higher the perceived job stress. These results indicate that the values 


\section{International Journal of Business Management and Economic Review}

Vol. 4, No. 06; 2021

ISSN: 2581-4664

contained in the workload can be perceived well and have a real impact on job stress experienced by the employees of Desak Putu Putera Cottages Group.

The high workload felt by employees can be seen from the psychological demands that interfere with their work, the perceived role ambiguity of the employee, lack of concentration at work, and experiencing mental disorders at work. With the high workload felt by employees providing a link to high job stress, this is reflected in employees often feeling frustrated at work, depressed at work, feeling tense at work and often feeling worried as a result of a high workload.

The results of this study are in accordance with the results of previous research conducted by Pratama \& Satrya (2018) at the Bali Provincial Transportation Service which shows that workload has a positive and significant effect on job stress. This is because an increase in workload accompanied by a lack of time to do work and a lack of opportunity to be able to make decisions at work results in an increase in job stress. The results of this study also support several previous studies conducted by Lestari \& Utama (2017), Yo \& Surya (2015), Kusuma \& Soesatyo (2014), Shabbir \& Naqvi (2017), Rizky \& Afrianty (2018), Wijaya (2018) , and Aujada, Saryadi, \& Nugraha (2015).

\section{The Effect of Job Stress on Employee Performance}

The job stress variable has a correlation coefficient of -0.343 and a t statistic value of 4.076 on its effect on performance, then H5 is accepted. This shows that there is a negative influence between job stress on performance. The higher the job stress felt by the employee, the lower the performance shown by the employee. The results of the analysis show that job stress has a negative and significant effect on employee performance. Job stress is measured based on: work frustration, pressure at work, feeling tense at work, and feeling worried about being able to affect the performance of the employees of Desak Putu Putera Cottages Group. This means that the higher the job stress of the Desak Putu Putera Cottages Group employees, the lower the performance. These results indicate that the values contained in job stress can be perceived well and have a real impact on the performance of the employees of Desak Putu Putera Cottages Group.

The high job stress felt by employees can be seen from employees who often feel frustrated, depressed at work, feel tense at work and often feel worried when carrying out their work. With high job stress felt by employees giving a link to low performance, this is reflected in the quality of work getting worse, work not being completed on time, lack of employee responsibility for their work, tasks expected by superiors are not fulfilled optimally, and formal requirements of the job. not met as a result of excessive stress experienced by employees.

The results of this study are in accordance with the results of previous studies conducted by Ahmad et al. (2018) which shows that job stress has a negative and significant effect on employee performance. These results also support several previous studies conducted by Kotteeswari \& Sharief (2014), Vijayan (2018), Shahid (2012), Ahmed \& Ramzan (2013), Saranani (2015), Kristanti (2017), and Kusuma \& Soesatyo (2014)

2) Testing the Mediation Role

Examination of the mediating variables in this study will examine the mediating role of job stress variables on the indirect effect of emotional intelligence on employee performance, and the mediating role of job stress on the indirect effect of workload on employee performance. The 
International Journal of Business Management and Economic Review

Vol. 4, No. 06; 2021

ISSN: 2581-4664

examination of the indirect effect in this study can be seen in the explanation of the results of the analysis in Table 9.

Table 9. Mediating Variable

\begin{tabular}{|c|c|c|c|c|c|}
\hline \multirow{2}{*}{ Mediation Variable } & \multicolumn{4}{|c|}{ Effect } & \multirow{2}{*}{ Description } \\
\hline & (1) & (2) & (3) & (4) & \\
\hline $\begin{array}{l}\text { Emotional Intelligence (X1) -> Job } \\
\text { Stress (M) -> Employee Performance } \\
\text { (Y) }\end{array}$ & 0.105 & 0.268 & -0.305 & -0.343 & Partial Mediation \\
\hline $\begin{array}{l}\text { Workload (X2) -> Job stress (M) -> } \\
\text { Employee Performance (Y) }\end{array}$ & $-0 . z 39$ & -0.244 & 0.407 & -0.343 & $\begin{array}{c}\text { Partial } \\
\text { Mediation }\end{array}$ \\
\hline
\end{tabular}

Primary Data, 2021

Performance

The Role of Job Stress in Mediating the Effect of Emotional Intelligence on Employee

Job stress is able to mediate the influence of emotional intelligence on employee performance. This result is shown from the mediation test carried out, which shows that the effects $1,2,3$, and 4 have significant values. Thus, job stress is able to partially mediated the effect of emotional intelligence on employee performance. Based on these results, it can be interpreted that the higher the emotional intelligence, the lower the job stress, so that in the end the employee's performance will increase.

The results of the analysis show that job stress is able to mediate the effect of emotional intelligence on employee performance. Job stress in this study partially mediates the effect of emotional intelligence on employee performance. Based on these results, it can be interpreted that the job stress variable is not able to fully mediate the influence of emotional intelligence on employee performance. Job stress can partially mediate the influence of emotional intelligence on the performance of the employees of Desak Putu Putera Cottages Group. The higher the job stress felt by employees, the lower the influence of emotional intelligence on employee performance.

The results of this study support research conducted by Abdillah (2013), which states that emotional intelligence has an indirect effect on employee performance through job stress. This shows that employees who are able to identify, utilize, understand, and manage their emotions well will indirectly tend to have good work results through low job stress. In addition, Rafiee (2013) also stated in the results of the study that the job stress variable acts as a partial mediator on the influence of emotional intelligence on employee performance. This study also supports the research conducted by Sanjaya (2012), which shows the results that job stress weakens the effect of emotional intelligence on employee performance.

The Role of Job stress in Mediating the Effect of Workload on Employee Performance

Job stress is able to mediate the effect of workload on employee performance. This result is shown from the mediation test carried out, which shows that the effects $1,2,3$, and 4 have significant values. Thus, job stress is able to partially mediated the effect of workload on employee performance. Based on these results, it can be interpreted that the higher the workload, the higher the job stress, so that in the end the employee's performance will decrease.

The results of the analysis show that job stress is able to mediate the effect of workload on employee performance. Job stress in this study partially mediates the effect of workload on 


\section{International Journal of Business Management and Economic Review}

Vol. 4, No. 06; 2021

ISSN: 2581-4664

employee performance. Based on these results, it can be interpreted that the job stress variable is not able to fully mediate the effect of workload on employee performance. Job stress can partially mediate the workload on the performance of the employees of Desak Putu Putera Cottages Group. The higher the job stress felt by employees, the higher the effect of workload on employee performance.

The results of this study support the research conducted by Shabbir \& Naqvi (2017) which states that job stress partially mediates the effect of workload on employee performance. In addition, research conducted by Martini \& Sitiari (2018) states that job stress partially mediates the effect of workload on employee performance.

3) Direct Effect, Indirect Effect, Total Variable Effect and VAF Calculation

Table 10. Direct Effects, Indirect Effects, Total Variable Effects and VAF Calculation

\begin{tabular}{|c|c|c|}
\hline \multirow{2}{*}{ Variable } & \multicolumn{2}{|c|}{ Direct Effect } \\
\hline & Path Coefficient & t statistics \\
\hline Emotional Intelligence (X1) -> Employee Performance (Y) & 0,268 & 1,997 \\
\hline Workload (X2) -> Employee Performance (Y) & $-0,244$ & 2,843 \\
\hline Emotional Intelligence (X1) -> Job Stress (M) & $-0,305$ & 3,406 \\
\hline Workload (X2) -> Job stress (M) & 0,407 & 4,134 \\
\hline Job Stress $(\mathrm{M})$-> Employee Performance $(\mathrm{Y})$ & $-0,343$ & 4,076 \\
\hline $\begin{array}{l}\text { Emotional Intelligence (X1) -> Job Stress (M) -> Employee } \\
\text { Performance (Y)) }\end{array}$ & 0,105 & 2,639 \\
\hline Workload (X2) -> Job stress (M) -> Employee Performance (Y) & $-0,139$ & 2,759 \\
\hline \multirow[t]{2}{*}{ 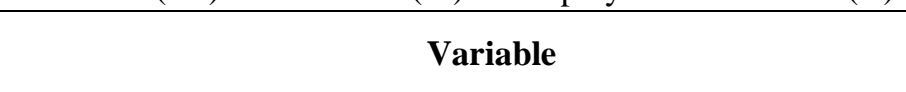 } & \multicolumn{2}{|c|}{ Total Effect } \\
\hline & Path Coefficient & t statistics \\
\hline Emotional Intelligence (X1) -> Employee Performance (Y) & 0.372 & 1.997 \\
\hline Workload (X2) -> Employee Performance (Y) & -0.384 & 2.843 \\
\hline Emotional Intelligence (X1) -> Job Stress (M) & -0.305 & 3.406 \\
\hline Workload (X2) -> Job stress (M) & 0.407 & 4.134 \\
\hline \multirow[t]{2}{*}{ Job Stress (M) -> Employee Performance (Y) } & -0.343 & 4.076 \\
\hline & \multicolumn{2}{|c|}{ VAF } \\
\hline VAF -> Indirect Effect / Total Effect $(0.105 / 0.372)$ & \multicolumn{2}{|c|}{0.282} \\
\hline VAF -> Indirect Effect / Total Effect (-0.139/-0.384) & \multicolumn{2}{|c|}{0.362} \\
\hline
\end{tabular}

Primary Data, 2021

The criteria for assessing the mediating effect can be based on the VAF value. If the value of VAF

$>80 \%$ then the mediation variable is full mediation, if $20 \% \mathrm{VAF} 80 \%$ then the mediation variable is partial mediation and if $<20 \%$ then the mediation variable is not a mediator. The results of the indirect effect test can be presented in Table 10.

The mediating role of the job stress variable is shown in Table 10. Initially, the coefficient of the direct influence of emotional intelligence on employee performance was 0.268 . The addition of job stress variable as a mediating variable has a different effect on the total influence of emotional intelligence on employee performance. Table 10 shows that the VAF value is 0.282 . The mediation value of 28.2 percent is between the range of $20 \%$ and $80 \%$. This means that the variable is classified as a partial mediation variable. In conclusion, the results in this study indicate that job stress can partially mediate the effect of emotional intelligence on employee performance. 


\section{International Journal of Business Management and Economic Review}

Vol. 4, No. 06; 2021

ISSN: 2581-4664

The mediating role of job stress variables in the effect of workload on employee performance is shown in Table 10. Initially the coefficient value of the direct influence of workload on employee performance was -0.244 . The addition of the job stress variable as a mediating variable has a different effect on the effect of the total workload on employee performance. Table 10 shows that the VAF value is 0.362 . The mediation value of 36.2 percent is in the range of 20 percent to 80 percent. This means that the variable is classified as a partial mediation variable. The results in this study indicate that job stress can partially mediate the effect of workload on employee performance.

\section{CONCLUSION}

The results of this study have shown that emotional intelligence has a positive and significant effect on employee performance, workload has a negative and significant effect on employee performance, emotional intelligence has a negative and significant effect on job stress, workload has a positive and significant effect on job stress, job stress has a negative effect. and significant on employee performance, job stress is able to mediate the effect of emotional intelligence on employee performance, and job stress is able to mediate the effect of workload on employee performance. Based on these findings, the results of this study are able to enrich the development of human resource management science, especially related to employee performance and support other empirical studies related to the role of job stress in mediating the influence of emotional intelligence and workload on employee performance.

The results of this study indicate that the job stress variable has the highest influence on employee performance, followed by the influence of emotional intelligence on employee performance. Thus, the management of Desak Putu Putera Cottages Group should pay more attention to the job stress experienced by its employees and the workload received by its employees. Because with job stress and low workload, employees are able to provide high performance to the company.

\section{Research Limitations}

This research is only limited to examining the effect of emotional intelligence, workload, job stress on employee performance. So that researchers did not examine more deeply about the factors outside these variables. Future research is expected to be able to examine more deeply about employee performance using other influential variables. In addition to this, the scope of this research is also limited to the work area of Desak Putu Putera Cottages Group, so it cannot be generalized to a wider area.

\section{REFERENCES}

Abdillah, W. 2017. Pengaruh Kepemimpinan, Stres Kerja, Disiplin Kerja, dan Kompensasi Dengan Kinerja Pegawai. Daya Saing. Jurnal Ekonomi Manajemen Sumber Daya, Vol. 12, No. 1, pp: $1-11$.

Aghdasi, S., Ali, R.K., Abdolrahim, N.E. 2011. Emotional Intelligence and Organizational Commitment: Testing The Mediatory Role Of Occupational Stress And Job Satisfaction. ProdiaSocial and Behavior Science Vol. 29, pp: 1965-1976.

Ahmad, E. H., Maidin, A., Abdullah, T., Naiem, F., Buraerah, S., Handayanif, R., \& Prihantono, 


\section{International Journal of Business Management and Economic Review}

Vol. 4, No. 06; 2021

ISSN: 2581-4664

P. 2018. Relationship of Work Stres to the Performance of Intensive Care Unit Nurses in Makassar. American Journal of Public Health Research, Vol. 6, No. 1, pp: 18-20.

Ahmed, A., \& Ramzan, M. 2013. Effects of Job Stres on Employees Job Performance A Study on Banking Sector of Pakistan. IOSR Journal of Business and Management, Vol. 11, No. 6, pp: $61-68$.

Akob, M. 2016. Influence Workload, Work Ethic and Job Satisfaction Toward Teacher's Performance. Global Advanced Research Journals of Management and Business Studies, Vol. 5, No. 7, pp: 172-177.

Alkubaisi, M. M. 2015. How can Stres Affect Your Work Performance? Quantitative Field Study on Qatari Banking Sector. Business and Management Research, Vol. 4, No. 1, pp: 99-109.

Arie, Fajriani. 2015. Pengaruh Beban Pekerjaan terhadap Kinerja Karyawan: Efek Mediasi Burnout. Jurnal Manajemen dan Kewirausahaan, Vol 7, No. 9, pp: 74-79.

Aujada, R., Saryadi, \& Nugraha, H. S. 2015. Pengaruh Beban Kerja, Lingkungan Kerja dan Pengawasan Terhadap Stres Kerja Karyawaan PT. Daya Manunggal Salatiga Departemen Weaving Ajl Ii. Diponegoro Journal of Social and Politic, Vol. 1, No. 1, pp: 1-10.

Chandra, R., Adriansyah, D. 2017. Pengaruh Beban Kerja dan Stres Kerja terhadap Kinerja Karyawan pada PT. Mega Auto Central Finance Cabang di Langsa. Jurnal Manajemen Dan Keuangan, Vol. 6, No. 1, pp: 670-678.

Chen, H., Wang, C. 2019. Incivility, Satisfaction and Turnover Intention of Tourist Hotel Chefs: Moderating Effects of Emotional Intelligence. International Journal of Contemporary Hospitality Management, Vol. 31, No. 5, pp 2034-2053.

Cheng, C. \& Chang, J. 2016. Job Embeddedness as A Modulation. Journal of Organizational Change Management, Vol. 29, No. 4, pp: 484-50.

Choi, H.M., Mohammad, A. A. A., Kim, W. G. 2019. Understanding Hotel Frontline Employees' Emotional Intelligence, Emotional Labor, Job Stress, Coping Strategies and Burnout. International Journal of Hospitality Management, Vol. 82, pp: 199-208.

Darvish, H., Nasrollahi, A. A. 2011. Studying the Relations Between Emotional Intelligenceand Occupational Stres: A Case Study at Payame Noor University. Economic Sciences Series, Vol. 1, No.2, pp: 38-49.

Dhani, P., Sharma, T. 2017. Effect of Emotional Intelligence on Job Performance of IT Employees: A Gender Study. Procedia Computer Science, Vol. 122, pp: 180-185.

Diane, S., Tremblay, G. 2016. Workload, Generic and Work-Family Specific Social Supports and Job Stress: Mediating Role of Work-Family and Family-Work Conflict. International Journal of Contemporary Hospitality Management, Vol. 28, No. 8, pp: 1778-1804.

Fitriastuti, A. 2013. Pengaruh Kecerdasan Emosional, Komitmen Organisasional dan Organizational Citizenship Behavior Terhadap Kinerja Karyawan. Jurnal Dinamika Bisnis, Vol. 4, No.2, pp: 103-114.

Gong, Z., Chen, Y., Wang, Y. 2019. The Influence of Emotional Intelligence on Job Burnout and Job Performance: Mediating Effect of Psychological Capital. Frontier in Psychology, Vol. 10, No. 1, pp: 38-54. 


\section{International Journal of Business Management and Economic Review}

Vol. 4, No. 06; 2021

ISSN: 2581-4664

Goswani, K., Talukdar, R. R. 2013. Relation Between Emotional Intelligence and Job Stres Among Engineer's at Managerial Level at Public Sector organization. IOSR Journal Of Humanities And Social Science, Vol. 7, No. 1, pp: 44-47.

Gozali, N. 2016. The Influence of Workload and Individual Characteristic on Job Satisfaction and Its Impact on Employee Performance (A Case Study at Indonesian Regional Statistics Office (BPS) of Deli Serdang and Serdang Bedagai Regencies). Jurnal Bisnis Dan Manajemen Eksekutif, Vol. 1, No. 1, pp: 39-46.

Harini, S., \& Kartiwi, N. 2018. Workload, Work Environment and Employee Performance of Housekeeping. International Journal of Latest Engineering and Management Research, Vol. 3, No. 10, pp: 15-22.

Hidayati, N. 2013. The Impact of the School Safety Zone on Passenger Car Equivalent Values in Indonesian Urban Roads. Procedia - Social and Behavioral Science, Vol. 54, pp: 13391349.

Iskandar, S., Sembada, G. G. 2012. Pengaruh Beban Kerja, Motivasi Dan Kepuasan Kerja Terhadap Kinerja Pegawai Bank BJB Cabang Padalarang. Jurnal Ekonomi, Bisnis \& Entrepreneurship, Vol. 6, No. 1, pp: 26-38.

Johari, J., Yean Tan, F., Tjik Zulkarnain, Z. I. 2018. Autonomy, Workload, Work-Life Balance and Job Performance Among Teachers. International Journal of Educational Management, Vol. 32, No. 1, pp: 107-120.

Karambut, C. A., Noormijati, E. A. T. 2012. Analisis Pengaruh Kecerdasan Emosional, Stres Kerja Dan Kepuasan Kerja Terhadap Komitmen Organisasional Studi Pada Perawat Unit Rawat Inap Rs Panti Waluya Malang. Jurnal Aplikasi Manajemen, Vol. 10, No. 1, pp: 655-668

King, L. 2011. Psikologi Umum Sebuah Pandangan APRESIATTIF. Jakarta: Salemba Humanika.

Koesomowidjojo, S. 2017. Paduan Praktis Menyusun Analisis Beban Kerja. Jakarta: Raih Asa Sukses.

Kokoroko, E., \& Sanda, M. A. 2019. Effect of Workload on Job Stress of Ghanaian OPD Nurses: The role of Co-Worker Support. Safety and Health at Work, Vol. 10, No. 3, pp. 341-346.

Kotteeswari, M., \& Sharief, S. T. 2014. Job Stres and Its Impact on Employees'

Performance a Study with Reference to Employees Working in Bpos. International Journal of Business and Administration Research Review, Vol. 2, No. 4, pp: 18-25.

Kristanti, E. 2017. Pengaruh Lingkungan Kerja Fisik Dan Lingkungan Kerja Non Fisik Terhadap Stres Kerja Dan Dampaknya Terhadap Kinerja (Studi Pada Kantor Bersama Samsat Mojokerto Kota). Jurnal Ilmu Manajemen, Vol. 5, No. 1, pp: 1-10.

Kusuma, A. A., Soesatyo, Y. 2014. Pengaruh Beban Kerja terhadap Stres Kerja dan Dampaknya terhadap Kinerja Karyawan. Jurnal Ilmu Manajemen, Vol. 2, No. 2, pp: 375-386.

Lambert, E. G., Jiang, S., Liu, J., Zhang, J., Choi, E. 2018. A Happy Life: Exploring How Job Stress, Job Involvement, and Job Satisfaction Are Related to the Life Satisfaction of Chinese Prison Staff. Psychiatry, Psychology and Law, 1-18.

Lestari, N. K. A., \& Utama, I. W. M. 2017. Pengaruh Konflik Interpersonal Dan Beban Kerja Terdadap Stres Kerja Karyawan Pt Pos Indonesia (Persero) Pusat Denpasar. E-Jurnal Manajemen Unud, Vol. 6, No. 12, pp: 6357-6382. 


\section{International Journal of Business Management and Economic Review}

Vol. 4, No. 06; 2021

ISSN: 2581-4664

Mangkunegara, P. 2013. Manajemen Sumber Daya Manusia Perusahaan. Bandung: PT. Remaja Rosida Karya.

Martini, B. \& Sitiari, W. 2018. The Effect Of Job Stress And Workload On Employee Performance At Hotel Mahogany Mumbul Bali. Jurnal Ekonomi \& Bisnis, Vol. 5, No 1, pp: 4145.

Megha. 2014. Hubungan Antara Kecerdasan Emosi Dengan Stres Kerja Distributor, Tesis, Universitas Islam Indonesia.

Mohamad, M., \& Jais, J. 2016. Emotional Intelligence and Job Performance: A Study among Malaysian Teachers. Procedia Economics and Finance, Vol. 35, pp: 674-682.

Naghdi, M. \& Badri, S. 2013. The Predicatablitity Of The Organizational Citizenshp Behavior Through Emotional Intelligence Dimensions In Personal Of Isfahan Municapitaly. Kuwait Chapter of Arabian Journal of Business and Management Review, Vol. 2 No. 5, pp: 3644.

Noormijati, 2012. Psikologi dalam Perusahaan. Jakarta: PT. Rineka Cipta.

Olusegun, E. 2014. Parents' Involve and Psycho-educational Development of Learners with Special Educational Needs (SENs): An Empirical Review. International Journal of Early Childhood Special Education (INT-JECSE), Vol. 6, No. 2, pp: 177-203.

Paramitadewi, K. F. 2017. Pengaruh Beban Kerja Dan Kempetensi Terhadap Kinerja Pegawai Sekretariat Pemerintah Daerah Kabupaten Tabanan. EJournal Management Unud, Vol. 6, No. 6, pp: 3370-3397.

Prajuna, A., Febriani, Hasan, L. 2017. Dampak Pengelolaan Kecerdasan Emosional Dan Stres Kerja Terhadap Kinerja Karyawan Pada Pt Mnc Sky Vision Kpp Padang. Jurnal Manajemen dan Kewirausahaa. Vol. 8, No. 2, pp: 15-26

Pratama, A., Satrya, H. 2018. Pengaruh Konflik Interpersonal, Beban Kerja terhadap Stres Kerja Pegawai di Dinas Perhubungan Provinsi Bali. E-Jurnal Manajemen Unud, Vol. 7, No. 8, 4570- 4598.

Rafiee, M., Kazemi, H., Alimiri, M. 2013. Investigating the effect of job stress and emotional intelligence on job performance. Management Science Letter, Vol. 3, pp: 2417-2424.

Rizky, D., \& Afrianty, T. W. 2018. Pengaruh Beban Kerja Terhadap Stres Kerja Dengan Work Life Balance Sebagai Variabel Intervening (Studi Pada Dinas Sosial Provinsi Jawa Timur Surabaya). Jurnal Administrasi Bisnis (JAB), Vol. 61, No. 4, pp: 47-53.

Robbins, Stephen, Judge, T. 2016. Perilaku Organisasi (Organizational Behavior). Jakarta: Salemba Empat. Kencana

Sanjaya, W. 2012. Strategi Pembelajaran Berorientasi Standar Proses Pendidikan. Jakarta:

Saranani, F. 2015. Role Conflict and Stres Effect on The Performance of Employees Working in Public Works Department. The International Journal of Engineering and Science, Vol. 4, No. 6, pp: 1-10.

Saranani, F. 2015. Role Conflict and Stress Effect on The Performance of Employees Working in Public Works Departement. The International Journal of Engineering and Science (IJES). Vol. 4 No. 6, pp: 1-10. 


\section{International Journal of Business Management and Economic Review}

Vol. 4, No. 06; 2021

ISSN: 2581-4664

Sawitri. 2015. Pengaruh Kecerdasan Emosional Dosen terhadap Perilaku Melayani Mahasiswa dan Kinerja Dosen di UPN Veteran Jawa Timur. Jurnal Psikologi Undip, Vol. 8, No.2, pp: $152-158$.

Shabbir, B., Naqvi, R. 2017. Impact of Workload and Job Complexity on Employee Job Performance with the Moderating Role of Social Support and Mediating Role of Job Stres: A Study of Travel Agencies in Rawalpindi, Islamabad and AJK. Journal of Accounting \& Marketing, Vol. 06, No. 01, pp: 1-7.

Shah, S., Ahsan, D., Jabran, A., Wasiq, E., Ihsan, U., \& Syed, R. 2011. workload And Performance of Employees. Interdisciplinary Journal of Contemporary Research In Business, Vol. 3, No. 5, pp: 68-69.

Shahhosseini, M., Silong, A., Ismail, I., Uli, J. 2012. The Role of Emotional Intelligence on Job Performance. International Journal of Business and Social Science, Vol. 3, No. 21, pp: 241246.

Shahid, M. N. 2012. Work Stres and Employee Performance in Banking Sector Evidence from District Faisalabad, Pakistan. Asian Journal of Business and Management Sciences, Vol. 1, No. 7, pp: 38-47.

Sunyoto. 2012. Manajemen Sumber Daya Manusia Edisi 2, Yogyakarta: CAPS (Center for Academic Publishing Service).

Vijayan, M. 2018. Impact of Job Stres on Employee's Job Performance in Aavin, Coimbatore. Journal of Organisation \& Human Behaviour, Vol. 6, No. 3, pp: 21-29.

Wakoli, C. 2016. Effects of Workload on the Teachers' Performance in Kanduyi Division, Bungoma District. International Journal of Science and Research, Vol. 5, No. 10, pp: 1215-1219.

Wijaya, A. 2018. Pengaruh Beban Kerja terhadap Kepuasan Kerja dengan Stres Kerja sebagai Variabel Mediasi pada Pekerja di Hotel Maxone di Kota Malang. Parsimonia, Vol. 4, No. 3, pp: 278-288.

Yamin, R., Wahyu, A., Ishak, H., Salmah, U., Patittingi, F. 2020. Effect of BMI, workload, work fatigue, and complaints of musculoskeletal disorders on nurse performance in Sawerigading Hospital Palopo. Enfermería Clínica, Vol. 30, pp: 403-406.

Yo, P. M. P., Surya, I. B. K. 2015. Pengaruh Beban Kerja Terhadap Kepuasan Kerja Dengan Stres Kerja Sebagai Variabel Mediasi. E-Journal Management Unud, Vol. 4, No. 5, pp: 1149-1165. 